\title{
EL VALOR DE LOS APRECIATIVOS EN JOSÉ JIMÉNEZ LOZANO
}

\author{
$M^{a}$ Teresa Domingo y Benito \\ I.E.S. Murillo de Sevilla
}

\begin{abstract}
The purpose of this article is to show the vivid speech that names the truth- what José Jiménez Lozano enunciate theoretically- becomes reality in his prose. The appreciative are very frequents in these texts, either in the narrator's voice- as a witness, as a writer or as an involved characteror in the dialogue. Through the evaluative suffixes is shown a great variety of affective shades associated with the character's life. They translate a vivid use, varied and extremely expressive.
\end{abstract}

\section{INTRODUCCIÓN}

A lo largo de la obra narrativa de José Jiménez Lozano abundan los personajes de gentes humildes, desvalidas, frágiles, pisoteadas a quienes el autor escucha y retrata con un extraordinario respeto y una profunda ternura.

En sus diarios y conversaciones muestra en repetidas ocasiones cuál es su poética. $<<$ La lucha del escritor es por encontrar las palabras que muestren lo real y lo levanten aunque sea de su sepultura, como decía Juan de la Cruz, las palabras carnales y verdaderas ${ }^{1}>>$.

Y en Segundo Abecedario precisa: $<<$ No se trata de lenguaje correcto, buen castellano, riqueza verbal y otras tonterías. Se trata de un sonido por el que se reconoce la verdad de lo que significa, como se reconocían los duros falsos de los que no lo eran o se reconoce un cuchillo de plata cuando cae al suelo. Se trata de más todavía: de un desposamiento o una lucha cuerpo a cuerpo, realizados a través de los sonidos ${ }^{2} \gg$. Todavía en Los tres cuadernos rojos añade: $<<$ Estos son los secretos del castellano: la sintaxis, la cantilenación, la absoluta adecuación de los adjetivos, etc. Nada de riqueza de vocablos, que es cosa de diccionarios, o de gentes ciudadanas que encuentran admirable que se llame atrases a unos atrases o bosta a la deyección seca de los animales, concretamente los bóvidos, es decir, a la bosta. Lo difícil es contar luego eso, y que siga sonando así, siga siendo esa carnalidad, o esa agua pura $>>^{3}$. (p. 14). Aún insiste ${ }^{4},<<$ Pero las palabras pueden dar vida o matar y su manejo debe ser tan delicado como el de los explosivos, los productos radiactivos, los venenos y las medicinas que se dosifican en fracciones de miligramos: más delicadamente

\footnotetext{
${ }^{1}$ J. Jiménez Lozano y G. Galparsoro. Una estancia holandesa. Conversación, Barcelona, Anthropos, 1999, p. 21.

2 José Jiménez Lozano. Segundo Abecedario. Barcelona, Anthropos, 1992, p. 178.

${ }^{3}$ José Jiménez Lozano. Los tres cuadernos rojos. Valladolid, Ámbito, 1986, p. 178.

${ }^{4}$ José Jiménez Lozano. La luz de una candela. Barcelona, Anthropos, 1996; pp.159-160.
} 
aún. Las palabras tienen aliento y una libertad imprevisible, una vez pronunciadas o escritas, una banalidad puede asesinar un alma $>>$ (p. 181).

Del corpus seleccionado, las novelas Duelo en la Casa Grande (1982) y La boda de Ángela (1993) se sitúan en la actualidad, más o menos próxima, aquélla en la postguerra, ésta en nuestros días. En ambas se refleja el habla coloquial: en la primera en un ámbito rural, en la segunda, un uso más urbano. Los relatos Sara de Ur (1989) y El mudejarillo ${ }^{5}$ (1992) recrean personajes históricos. En ellas el narrador, "escriba" o "escritor privado", respectivamente, muestra su afecto por los protagonistas. Todas estas novelas comparten un narrador que tiene que ver con la historia, bien porque está implicado en los sucesos y los cuenta -Ojo Virule y Toño, en Duelo en la Casa Grande; o el tío de Ángela-, bien porque actúa como transmisor de una historia que, aun no habiéndola vivido, le ha interesado. De ahí que dominen los diminutivos que desempeñan una función preferentemente expresiva, en algún caso, apelativa ${ }^{6}$. Cuando se trata sólo de valores nocionales relativos al tamaño se emplean los adjetivos adecuados. En los cuentos de El grano de maíz rojo, varían los escenarios y los narradores.

El propósito de este trabajo es mostrar cómo lo que enuncia teóricamente, como deseo, el autor se hace realidad en su prosa.

Desde estas bases, se estudiará el empleo y el valor de los apreciativos. Vaya, por delante, que en los textos revisados son muy frecuentes, por las razones ya dichas, y que se han desechado las formas lexicalizadas, tales como: cuartelillo, pililla del agua bendita, solanilla ${ }^{7}$, etc.

1. DIRIGIDAS AL OBJETO MENTADO, dominan las formas en -illo, -ito, las más comunes en la zona occidental del país. De ellas se elige en cada caso las más usuales. Estos sufijos los emplea el autor más frecuentemente con sustantivos que con adjetivos, y aún menos con adverbios, por tanto, valorando más la esencia que la cualidad. En alguna ocasión, muy señalada, se asocian con ambos miembros en un sintagma. Por ser los más empleados, se estudiarán en primer lugar.

1.1.- ILLO, -ILLA cuyo uso literario es muy anterior al de -ito ${ }^{8}$, quizá, por los orígenes latinos de aquél (<-ĔLLUS) y cuya frecuencia se equiparará a partir del siglo XVIII ${ }^{9}$. Aquí, sin embargo, domina, con mucho, -illo.

1.1.1. Aparece combinado con sustantivos en los que el uso prefiere -illo.

\footnotetext{
${ }^{5}$ Duelo en la Casa Grand, Barcelona, Ánthropos, nov. 1982. La boda de Ángela. Barcelona, Seix-Barral, oct. 1993. Sara de Ur, Barcelona, Ánthropos, mayo 1989. El mudejarillo, Barcelona, Ánthropos, octubre 1992. El grano de maíz rojo, Barcelona, Ánthropos, julio 1988. Siempre se trata de la primera edición.

${ }^{6}$ No olvidemos que El mudejarillo ha sido representado, con gran acierto y extraordinaria fidelidad al texto, por Isabel Ordaz.

${ }^{7}$ Cf. "Doramembrillos", La última de El Semanal, 26 de septiembre 1999.

${ }^{8}$ Por primera vez apareció en un texto literario en la Representación del Nacimiento de Nuestro Señor, de Gómez Manrique: "Callad vos, Señor,/ nuestro redentor,/ que vuestro dolor/ durará poquito./ Ángeles del cielo,/ venid dar consuelo,/ a este moçuelo/ Jhesús tan bonito." Después lo usan autores que reflejan la tendencia popular: Encina, fray Antonio Montesinos, La Celestina. Nebrija lo registra ya como un sufijo diminutivo.

${ }^{9}$ Cf. R. Lapesa, Historia de la Lengua Española. Madrid, Gredos, 1980.
} 
El habla de los castellanos emplea la forma -illo, mientras que en Sevilla domina -ito, en este caso concreto ${ }^{10}$ :

$<<$ se tenía que correr continuamente hacia el solillo $>>($ Duelo, p. 106).

En ambas regiones, se usa -illo:

$<<$ Allí vendía ajorcas y pendientes, collares, brazaletes y pulseras, perfumes y telas de colores. Pero sobre todo idolillos: imágenes de dioses y diosas con ojos de concha, que miraban fijamente como búhos >> (Sara, p. 29).

Hay un elemento anticipatorio y recurrente que tiene una importancia capital en este relato. En el taller de Teraj, se enamoraron Sara -de catorce años- y Abram -un chico muy serio-. Éste, prendado de la joven, le mostró los animales que su padre había comprado a los mercaderes y los que él mismo talló, a uno lo identifica como "joya"11.

$<<$ Un carnero de plata vieja enredado en unas zarzas de opalina y lapislázuli con escaramujos de oro viejo $>>$ (Ibídem, p. 31).

joya que ella regaló, a su vez, $<<$ al Faraón de los Misrim, enredado en las zarzas de su amor $>>$ (p. 53); por eso, pasado el tiempo, les encargará a otros mercaderes <<una estatuilla de plata $>y$, de paso, les compró un cuchillo de monte para Abram. Cuando éste, siguiendo las instrucciones de El Shadday, va a subir al monte con Is'hac, para ofrecerle un sacrificio, pregunta a Sara si ha incluido en el equipaje el cuchillo. Una vez en Moryac, preparada la víctima, apareció un $<<$ jinete veloz y hermoso como el rayo $>>$ que $<<$ derribó a Abram a tierra de un golpe fuerte en el rostro $>>$ :

$<<$ Debió de pasar mucho tiempo hasta que Abram pudiera levantarse y desatar al muchacho. Y todavía sólo fue más tarde cuando por fin se percataron de que, entre la niebla y enredado en unas zarzas, un carnero aún joven balaba prisionero y herido. Is'hac lo liberó con cuidado y lo dio de beber agua, pero Abram se echó sobre el animal, de repente, y lo degolló, haciendo de nuevo temblar el corazón del muchacho >> (Ibídem, p. 95)

Es el episodio central en la vida de Abram y Sara y, sin embargo, no aparece ni un sólo diminutivo: Sara está ausente.

Los animales jóvenes o pequeños de tamaño se nombran con -illo: ratoncillo ${ }^{12}$, perrilllo de aguas, corderilllo, cervatillo, cabritillo..., por todos hay afecto. Los pájaros que alegran la vida a diario son $<<$ los jillguerillos [que] parecían muchachos de aquí $>>$ (Duelo, p. 68); y Juan de la Cruz que, ante el Tribunal, era $<<$ como un gorrioncillo, como un silbo, como nada, pero

\footnotetext{
${ }^{10}$ Según M. Seco, -illo es el uso preferente en Sevilla; p. 188 de la Gramática esencial del español. Madrid, Aguilar, 1974. Sin embargo, se toman copitas -un vinito o una cervecita fresquita- por pasar un ratito, con unas tapitas o con pescaito frito -chanquetitos, salmonetitos, pijotitas- acompañado de regañitas; nos echamos un cigarrito; los niños se montan en las calesitas o en los cacharritos en la calle del Infierno; en invierno, si estamos heladitos, nos tomamos un cafelito, que cuesta un dinerito, y damos un paseito al solito. Si hace falta, nos esperamos un momentito.

${ }^{11}$ Pero, en adelante, ¿cuál es la joya?, ¿sólo la estatuilla?; o más bien ¿la que entregó Abram al Faraón, es decir, Sara para salvar su vida? o, aun, ¿la que iba a sacrificar a El Shadday, esto es, Is'hac?.

12 "y el ratoncillo: ¡hi, hi, hi! como un niño pequeño que llorase" (Duelo, p. 83) puede indicar compasión; pero en el proceso a fray Juan: "los zapatos relucientes de sus jueces, de dos en dos, como ratoncillos" (p. 91) no hay afecto, hay rebajamiento e insistencia en la debilidad de quien necesita imponer su razón por la fuerza.
} 
de la Cruz que, ante el Tribunal, era $<<$ como un gorrioncillo, como un silbo, como nada, pero presidiendo $>>$ (Mudejarillo, p. 93), o ya camino de Úbeda, enfermo, $<<$ pesaba lo que un gorrioncillo $>$ (Ibíd., p. 155). En todos los casos es afectuoso y, a mi juicio, no cabe el derivado en -ito, de ahí que en todos los textos se diga sólo gorrioncillo.

Al describir el escriba a Sara dice varias veces:

$<<$ era como una cervatilla de ojos ingenuos y su risa como cuando un cristalito se quebraba al incrustarlo $>$ (p. 32)

$<<$ los pequeños senos de Sara, como manzanas en agraz o dos cervatillos blancos ${ }^{13}>>$ (p. 16)

Aunque el diminutivo esté lexicalizado en español y la imagen, consagrada en los libros poéticos de la Biblia ${ }^{14}$ y en la lírica tradicional, aporta toda su carga cultural; el narrador todavía añade: $<<$ Pero es que era ágil y flexible como una corza de un año solamente $>>$ (p. 11), que pertenece al mismo campo semántico que las voces anteriores: lo deseable.

Teresa y Juan llevaban a cabo las fundaciones en aldeas o pueblos pequeños, allí en las casas, que les dejaban ${ }^{15}$, establecían los conventillos y tenían sus celdillas. Se está encareciendo la modestia.

Rebujo es, de por sí, pequeño. Para el frailecillo, suficiente:

$<<$ porque entendía mucho de [...] rebojillos de pan, cuando se los daban $>>$ (p. 102).

A fray Juan le tentaban con que fuera Maestro, como los de Salamanca, o con que predicara en los días señalados, pero

<<él prefería pedir dos monedas de nada o un rebojillo de pan en la calle $>>$ (p. 109).

Necesidad pasó mucha Juan desde niño, no olvidemos que su hermano Luis murió de inanición, y siguió pasándola de adulto. A veces no había nada que comer en el conventillo

$<<$ Y fray Juan les hacía una plática, iy tan contentos!; aunque los estómagos hacían rún-rún, rún-rún, pero se aplacaban en seguida con un mendruguillo $>>$ (p. 102).

Se comprende así cuánto de estimable era el trozo de pan dado y pedido por amor de Dios.

$<<$ Unas calenturillas $>>$, quitándoles importancia, llama Juan de la Cruz a las que padeció en Ávila y así las nombra, respetándolo, el escritor privado (p. 85).

$\mathrm{Al}$ acusarlo ante Micer Doria dicen de él:

$<<$ Que era muy moreno y de barba recia, y muy pobrecillo $>>$ (p. 148).

La intención de los delatores es negativa y el diminutivo adquiere aquí una connotación peyorativa, el desprecio. Lo mismo los inquisidores y $<<$ las gentes de sombrero y

\footnotetext{
${ }^{13}$ Nótese el adjetivo.

${ }^{14}$ En el Cantar de los Cantares, dice el Coro: "tus dos pechos son dos mellizos de gacela/ que triscan entre azucenas" -3, 5- o "tus senos dos cervatillos" -7, 4-, "no tiene pechos todavía" -8, 8-.

15 "algo que tuviese cuatro paredes y cosa parecida a un tejado" José Jiménez Lozano, "Excursión de verano", $A B C, 19$ de julio de 1999, p. 3.
} 
pretendiendo desacreditarlo. El $<<$ escritor privado $>>$ recoge esta denominación aunque disienta de ella, quizá burlándose de la perspicacia de los poderosos.

La gente de la aldea en la que sucede el Duelo en la Casa Grande es gente humilde, sencilla. Los hombres visten su pantalón de pana y su boina o su gorra a la que dan vueltas entre las manos, colocadas sobre o entre las rodillas, cada vez que se encuentran en una situación de inferioridad y sienten temor:

$<<$ con la gorrilla entre las manos como todos nosotros siempre que tenemos que explicarnos, y aunque eso le ponía nervioso al cabo Pérez: ¿Es que no te puedes estar quieto con la gorra, Ojo Virule? Pero también se daba cuenta el cabo de que era nuestra defensa, porque las mismas vueltas que damos a la gorra entre las manos son las que damos al magín en la cabeza y como si fueran a una y de concierto. Yo desde siempre daba esas vueltas, en las conversaciones con los de arriba, y mucho más con la gorra de plato de alguacil (Duelo, p. 131).

Para estos hombres es casi instintivo y como un consuelo, el mismo gesto hará Barragán, <<andaba trasteando con la gorrilla $>>$, mientras le está interrogando el abogado. Véase que para quien se ase a ella es gorrilla, lo valorado, lo imprescindible, y en otras circunstancias o para el otro: gorra, lo genérico.

El contraste lo ofrecen $<<$ la chaquetilla blanca $>>$ (p. 9) que con tanta prestancia luce el gobernador o las $<<$ cintillas de las hombreras $>>$ (ibid) del alguacil enterrador, con que ambos indican su autoridad.

Del mismo modo contrasta la modestia en el vestir de la Rosa, la criada chica en casa de Toño, <<está en todas estas fotos con un vestidillo de percal y una chaquetilla de punto $>>$ (Ibíd, p. 17).

1.1.2. Asociado a una noción dimensional, es decir, a objetos de una especie que pueden presentar distintos tamaños, pero que aquí, aun pequeños, son valiosísimos para sus dueños.

-Del huertecillo, habla continuamente Ojo Virule y precisa $<<$ el cacho huerto que usted sabe donde en el verano nos comemos los tomatillos $>>($ Duelo, p. 111). Tratando de reconquistar la amistad del cabo Pérez o, al menos, de conseguir su connivencia.

Un pradillo, fundamental en este relato, es donde se ejecutaban los fusilamientos, aquél queda marcado por el dolor que se siente por los asesinados.

-El mudejarillo, ése es el título del relato en que se refleja la época y el talante de Juan de la Cruz. Al morir:

$<<$ el rostro de fray Juan se puso blanco como las azucenas, que no podía decirse entonces que había sido en vida como el de un mudejarillo >> (p. 164)

Resume este apelativo sus orígenes humildes, de una casta minoritaria y sospechosa y su talla de $<<$ poquita cosa $>>$. Para el escritor privado que recoge su historia es afectuosísimo.

-Gracias al telarcillo de la señora Catalina sobreviven los de Yepes: 
$<<$ Y allí tenían el telarcillo, que estaba junto a la cocina, en el cuarto de adentro $>>$ (p. 34), $<<$ un telarcillo: trac-trac-trac, trac-trac-trac; y los vecinos y los que pasaban por allí decían:Desde que amanece Dios, está ahí dándole la Catalina > (p. 25).

Al ser el único medio de conseguir algún ingreso el telar es fundamental, por tanto, se subraya lo valioso del objeto y lo familiar incorporando, además, la onomatopeya.

-También es sistemática, una vez que profesa, la mención a Juan como el fraillecillo: $<<\mathrm{el}$ fraillecillo Juan $>>$ (capítulos 18 y 20), <<el fraillecillo de Medina $>>$ (cap. 19), <<el fraillecillo fray Juan $>>$ (cap. 23) y, en adelante, sólo $<<$ el fraillecilllo $>>$, pero sus hermanos de Orden serán sólo $<<$ frailes $>>$ para el narrador. Claro que es Juan quien despierta el interés y el afecto del $<<$ escritor privado $>>$, y que su talla era menguada aunque su importancia, inmensa.

\subsection{3. -illo con valor contrastivo.}

\subsubsection{1.- -illo /vs/ -ejo}

Sirve para distinguir dos situaciones. En los días de diario, $<<$ con mi oficio y la partidilla me basta $>$ p. 133), dice Ojo Virule; pero la partideja será excepcional:

$<<$ a Chichola Sacris] por su oficio los velorios le tiraron siempre, lo contrario que a mí, [...] como no sea para echar una partideja o por si cae algún refrigerio $>>$ (p. 30).

Probablemente sea el contexto el que tiñe al vocablo de un matiz negativo en el Duelo, esta posibilidad le llevará a participar en una partida excepcional y traidora.

\subsubsection{2. - -illo /vs/ -ín}

De un esquilín -pp. 57, 92 y 95- se colgó don Acisclo. Se emplea para destacar el contraste entre la pequeña campana y la tragedia del campanario. $<<$ Una esquilillla precedía al carro de los muertos $>>$ (El mudejarillo, p. 115), <<el año del catarro universal $>>$. Hay, desde luego, diferencia de tamaño entre ambos, pero también las muertes son diferentes.

\subsubsection{3.- En ocasiones, el contraste se establece con el primitivo.}

-Sara juega ${ }^{16}$ y se divierte con los cabritillos, y sus esclavillas son, también, sus cómplices y confidentes. En el primer caso, la lengua no admite otro diminutivo que -illo; en el segundo, el diminutivo sirve para distinguir las propias de las ajenas, las que pertenecen al Faraón serán siempre esclavas y Agar es una $<<$ esclava egipcia $>>$ (cf. cap. V)- mientras existe rivalidad entre ellas; cuando ésta se sienta, como Sara, desgraciada se preguntará el escriba, mostrando su compasión:

$<<$ ¿adónde podía ir una esclavilla egipcia con el vientre abultado, por el desierto y bajo el sol? >> (Sara, p.46).

Los hijos, Ihsma'el e Is'hac, <<jugaba[n] al escondite entre los cabritillos y las esclavillas $>>$ (p. 70). El contraste se establece, pues, con el primitivo. Mucha menor familiaridad se tiene con las criadas, aunque sean criaditas: $<<$ Nofret necesitaba ella sola

\footnotetext{
$16<<$ al juego de las tiendas con esas sus criadas y esclavillas $>>$ (p. 51). Criadas está resaltado con el doble determinante.
} 
un ejército de criaditas y siervos $>$ (Ibíd., p. 55); claro que el diminutivo en -illa designa en español otro referente.

Sin embargo, a Juan, en el hospital de Medina, $<<$ todos le nombraban su mayordomo o criadillo $>>$ (Mudej., p. 49) y sentían por él cariño.

-Con un pucherillo hacen la cola a la puerta del convento en Fontiveros los vecinos de Catalina, la de Yepes, y ella misma:

$<<$ Una larga fila de hombrecillos y mujeres flacas, niños muy serios y quietecitos a la puerta del hospital de San Cebrián del pueblo. Llevan un pucherillo de barro en las manos y un pañizuelo sobre él, y otra fila de hombres, mujeres y niños salen ligeros de alli ${ }^{17}$, como saltando o también, los más viejos llevando su puchero junto al pecho y la otra mano sobre el pañizuelo que tapa al pucherillo, como los curas llevan el viático. Pero luego to/dos aceleran su paso apenas entrevén sus casitas de adobe, para socorrer el hambre de los que esperan allí dentro y, si queda algo todavía, el suyo >> (Mudej., pp. 14-15).

Hay una gradación entre un pucherillo, aún no identificado, su puchero junto al pecho y al pucherillo: cuando vuelven con él lleno enfatizan el posesivo que determina al nombre primitivo y la preposición que precede al complemento directo nombra otra vez lo muy apreciado. El recipiente ha crecido en importancia. Y es que el contenido del puchero casi lo humaniza, al menos lo anima, el caldo les es vital; como dice la lengua coloquial es $<<$ un caldo que resucita a un muerto $>>$ y muertos de hambre estaban los pobres.

\section{- Cordero/vs/ corderillo}

La denominación habitual es corderillo, cuando se nombra en los textos, pero hay dos cuentos sumamente ilustrativos.

En El cordero, el niño jugaba con los corderos, se dormía sobre su lana,

$<<$ Recordaba esos instantes contra la mañana [...] Y, al final, lo peor de todo: el balar del corderillo cuando iban a buscarlo al corral, como el llanto de un niño $>>$ (p. 25)

$<<$ pero, en seguida, comenzó a darse cuenta de que el corderillo era cada noche distinto, aunque él le había puesto ya un nombre, y que lo mataban a la mañana siguiente. De modo que no quiso jugar más a este juego, ni quería ver tampoco a sus padres [...], porque ¿acaso no ataba ella al corderillo, como la había visto hacer una mañana por la puerta de la cuadra entreabierta, y no le sujetaba el cuello luego, mientras su padre hendía el cuchillo en la garganta? [...] Sólo un día no había sacrificio, como les había oído decir: el Viernes Santo»> (p. 26).

$<<$ Y, al final, cuando ya era un hombre, se marchó de casa hacia un país lejano donde no hubiera cruces, ni calvarios o mataderos, ni balidos de desvalimiento y ojos de corderos asesinados; y donde nadie le conociera por cristiano, ni hijo del carnicero >> (p. 27).

El amor y la piedad por el animal, al que humaniza con la primera comparación, choca con la violencia de la escena de la matanza, a la que llama, primero, sacrificio y, luego, asesinato. El sacrificado le inspira compasión. Del deseo de apartarse de ese mundo advierte el título: un cordero es un muerto, una víctima. Semejantes son los sentimientos

\footnotetext{
${ }^{17}$ Ahora sin adjetivos, porque lo que cuenta es el pucherillo y la prisa con que regresan a sus casas.
} 
de El zagalejo, cuyo final es aún más trágico: aquel hombre se fue por esos caminos, éste, que había manifestado ante sus compañeros viejos que nunca mataría un cordero o un cabritillo, en el convite de su boda ve que

$<<$ ahora se estaban sirviendo los corderos y cabritillos [...] El zagalejo se levantó de su asiento con un cuchillo y un tridente y se disponía a trinchar la carne sobre la fuente [...] Pero, entonces, alzó el zagalejo sus ojos y vio sonreírse a los viejos, y comprendió>> (p. 46)

y esa misma noche se colgó de una viga en el aprisco. Parece que la tragedia se presentía en el contraste entre corderos, con el valor que hemos visto en el cuento anterior, y cabritillos que recogería el de los corderillos de antes: se sintetizan los dos sentidos.

- Escalera/vs/ escallerillas.

Escallerillas llama, a lo largo del relato, el tío de Ángela a las que conducen a la ermita. Como recuerda A. Alonso ${ }^{18}$ de su experiencia infantil, las escalerillas son para los niños un elemento más de sus juegos; con esa emoción que provoca el recuerdo de la niñez -que se superpone al relato del evento- lo ha empleado por doquier el narrador. Sólo que al final, cuando el enlace no se lleva a cabo, y el marido de Lita baja por la escalera ésta se torna en una barrera muy seria, fundamental, significa la ruptura con el mundo frívolo y la decisión de Ángela de incorporarse a la familia materna, a los valores de ésta y de la tía Tesa, a lo auténtico, de no ser otra víctima más del padre ${ }^{19}$ quien, finalmente, ha sido vencido de ahí $<<$ su precipitarse por la escalera $>>$ (p. 138). Ello supone que no podrá enriquecerse con la boda de la hija, pero para la familia materna la repercusión es aún mayor:

$<<$ Creo que nos hemos arruinado del todo, y con este escándalo de la boda hemos roto todas las amarras con el mundo -dijo mamá, cuando llegamos a casa $>$ (p. 139),

sin embargo, eso no representa una tragedia sino el conseguir un ideal de vida más cercano al evangélico. En escalera hay una concepción global, en escalerillas se valora cada peldaño.

\section{- Enano/vs/ Enanillo.}

Con un sentido afectivo se emplea el término enanillo, en el capítulo titulado La huida de El mudejarillo.

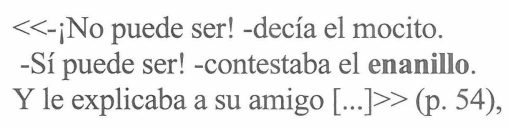

$<<$ Como otro enanillo amigo suyo, que conocía él, y se había escapado de la casa de su señor con una esclavilla negra $>$ (p. 55).

En ambos casos se siente ternura, compasión, por estos seres y es que como la señora Catalina

\footnotetext{
$18<<$ Noción, emoción, acción y fantasía en los diminutivos >> en Estudios lingüísticos. Temas españoles. Madrid, Gredos, 1982; pp. 161-189.

${ }^{19}$ Carece de nombre propio identificador, sencillamente, porque no se lo merece, lo mismo ocurre con Monseñor.
} 
le recomienda:

$<<-$ iQue comas bien! Que tienes que comer para crecer y no quedarte como un enano, hijo; que luego se ríen todos de ti>> (p. 55).

Enano se refiere aquí a lo genérico, mientras que los enanillos son individuos particularizados. La elección del sufijo -illo y no -ito, también posible, podría deberse a que al estar establecido en el cuento Blancanieves y los siete enanitos, se quieran distinguir y valorar los sufrimientos y la realidad de estas gentes de carne y hueso, aunque sean un juguete para los poderosos como le sucedió a María Bárbola.

Por ese mismo temor, se pondera el que el mozalbete diera $<<$ un estironcillo $>>$ (p. 56).

Estraperlo /vs/ estraperlillo.

$<<$ El mismo cabo Pérez lo comprendía muy bien, aunque ahora dice que no comprende nada, pero se le nota que es que tiene que decirlo por su oficio, porque siempre cerró los ojos y volvió la cara ante el estraperlillo de los pobres como ante la máquina de retratar [...] y como con el estraperlo en fuerte de los ricos no puede hacer nada porque ya es cosa de arriba $[\ldots]>>$ (p. 117).

El primero produce compasión, es el medio para sobrevivir; el segundo es fruto de la codicia, despreciable, pues.

1.1.3.4.- En contraposición con -ito éste se lleva la peor parte. Siempre el elemento positivo va marcado con -illo.

En La boda de Ángela ya se ha dicho que el narrador es su tío quien le cuenta el suceso a su hermana Tesa, ausente; por tanto se relata desde el punto de vista de este personaje que está presente e implicado en la acción.

Él siempre se refiere al lugar donde ha de celebrarse la boda como la ermitilla, entre otras razones, porque forma parte de sus vivencias y de sus lugares familiares, también, probablemente, amoeni. Sin duda, el recinto no es muy grande, pero, en cualquier caso, se trata de despertar una emoción compartida con el destinatario por el paisaje:

$<<$ Ya sabes que desde la ermitilla se ve perfectamente la carretera [...] un poco después de que a la izquierda salga el caminillo de tierra que lleva a la finca $>>$ (p. 7),

$<<$ la espadañilla del oratorio $>>$ (p. 48),

$<<$ los invitados] Entraban, miraban allí dentro, y quedaban todavía más desilusionados por aquellas paredes desnudas, blancas y alabeadas; aquel arquillo de medio punto, de piedra rugosa, que/ se abre al ábside con tres ventanas saeteras, sin un adorno ni filigrana tallados. Y luego el altarcillo como un vasar, y encima la virgencilla románica con sus ojos de almendra, $\tan$ grandes y $\tan$ fijos $>$ (pp .8-9).

Sigue entusiasmándoles a ambos, sin embargo, los mundanos, es decir, los invitados $<<$ entraban y salían de la iglesita $>>$ (p. 10) ante la que $<<$ Abrían un poco los ojos y plegaban los labios los hombres; y soltaban una risita las mujeres:

-Es una joya.

[...] ¡Qué pena! Con lo mona que es. Como una casa de muñecas $>>$ (p. 9). 
Los invitados esperaban un boato que, al no encontrarlo, les decepciona, pero sirviéndose de estos tópicos vulgares muestran su saber estar en sociedad y su no entender nada de lo que les es ajeno. El narrador emplea aquí -ito para marcar las distancias: a los visitantes el lugar no les dice nada por eso muestran sólo su sorpresa, con grititos (pp. 40 y 124), y él interpreta así su comportamiento:

$<<$ como si todos aquellos burgueses se hubieran equivocado de lugar en un fin de semana, y hubieran ido a parar a un lugar extraño >> (p. 10).

Las risitas son o ridículas y falsas ${ }^{20}$-como en el caso anterior- o un enigma para el otro como las de $\mathrm{Sara}^{21}$-. Pero frente a estas risitas se recuerda la tosecilla del padre, es decir, del abuelo materno de Ángela quien la empleaba

$<<$ sobre las conversaciones de dinero o de mujeres $>>$ (p. 21), $<<$ como si con la tosecilla quisiera dirigir todo por otro derrotero $>>$ (p. 22).

Todo lo que allí viven los invitados les es incómodo y, por eso, mientras esperan la llegada de monseñor $<<$ el vientecillo del norte se hizo notar un momento [...] y más o menos disimuladamente casi todo el mundo dio un par de pataditas sobre el suelo $>>$ (p. 75).

No pueden prescindir del confort y cualquier alteración les molesta. Con las pataditas muestran su desasosiego.

En El mudejarillo, combinado con -ito pueden tener los dos valor positivo, muy positivo, y se destacan ambos: <<alzó los ojos hacia una criadita morisquilla $>>$ (p. 152).

El frailecillo Juan se identifica con la muchacha por sus orígenes comunes y por su vocación de servicio, también él comenzó asistiendo a los enfermos moribundos del hospital. Hay cariño y entusiasmo no exento de piedad. Y las chicas se identifican con él: $<<$ a las dos criaditas moriscas que había en la casa que les parecía como $\mathrm{si}^{22}$ fuera uno de los suyos, de lo humildito que era $>$ (p. 151). Es la ponderación de una cualidad.

\subsubsection{5.- Asociado a nombres propios.}

En el corpus seleccionado sólo se da un uso, dice el escriba de los padres respecto del trato de Ihsma'el a Is'hac: $<<$ Y éstos le mostraban unos juncos tren/zados con los que le azotarían, si trataba así a Isaacillo $>>$ (p. 74).

Aunque a Ihsma'el le alegrara el nacimiento del hermano, pasado el tiempo, unas veces le mima $<<$ jugaba con él al escondite entre los cabritillos y las esclavillas $>>$ (p. 70) y otras le chincha $<<$ le dejaba encerrado en una cuadra con los cabritillos $>>$ (p. 73); de manera que

\footnotetext{
${ }^{20}$ En el Duelo en la Casa Grande dice Ojo Virule: "porque a mí las risitas así de conejo y retorcidas" -p. 82-.

21 "Y Sara soltó una risita" (p. 82) de esas que llevaban a Abram a preguntarle ¿de qué te ríes? y a que ella respondiera no me río.

${ }^{22}$ Valor de conjetura "en el cual la predicación subjuntiva se presenta como resultado de nuestra interpretación" S. Fernández Ramírez . Gramática del español. 4. El verbo y la oración Madrid, Arco Libros S.A., 1986, p. 525.
} 
los padres tuvieron que reprenderle y salir a defender al más débil, la víctima: Isaacillo ${ }^{23}$. Muestra un gran afecto por el desvalimiento del que es inferior por la edad.

1.1.3.6.- No es habitual que se asocie con adjetivos, por tanto, es muy significativo cuando esto ocurre. Así, en El mudejarillo, los enfermos del hospital $<<$ cuando estaba de enfermero con los desambridillos e inapetentes $>>$ (p. 154), y ya en su última enfermedad, fray Juan <<estaba desambridillo y nada comedor $>>$ (ibidem). Sin embargo, algunos pobres estudiantes que estaban de pupilaje en Segovia acudieron al convento de la Fuencisla en busca de socorro, $<<$ los más hambridillos $>>$ (p. 142) y consumieron el escaso condumio de los frailes: unas coles que, por su olorcillo, les pareció a los ajenos manjar.

1.1.3.7.- Este sufijo aparece en dos locuciones adverbiales: <<porque esta boda, además, fue casi a tapadillo $>>$ (Duelo, p. 11), <<Íbamos todos a la carrerilla a misa $>>$ (Ibídem, p. 71); intensificando la acción.

1.1.3.8.- Consideremos en último lugar los casos en que la oposición se establece entre varias opciones.

\section{-ratillo/ratito/ratejo}

Salidos de Arévalo los de Yepes, ya a la vista de Medina

$<<$ pararon un ratillo a descansar y a consolarse un poco con la sombra y el agua de un pequeño soto que había allí con cinco o seis chopos muy altos y frondosos junto al río >> (Mudej., p. 43).

Evidentemente, aquí es valorativo: entre el cansancio y la emoción por tener a la vista el destino, se ofrecen un deleite, ante lo que se presenta, a distancia, como un locus amoenus $^{24}$.

$<<$ Otro gallo le hubiera cantado a usted, cabo Pérez, si hubiera usted ido allí de servicio toda la noche y no un ratito como persona particular a echar un pésame y un rezo $>$ (Duelo, $p$. 49).

Aquí se lamenta por lo perdido y, porque de haber sucedido según indica, no se hubiera producido el caso.

$<<0$ el otro ratejo que estuve estirando un poco las piernas con Pablo Barragán, Bruno Donel y Pablo Cigarra, a la puerta misma de la casa a olvidarnos del muerto ¿no?>> (Ibídem, p. 33).

Tiene el mismo valor que en partideja, lo inhabitual, después lamentable.

\section{-animalitos/animalillo/animalejos}

Con distinta valoración, ninguna negativa, se emplean en:

\footnotetext{
${ }^{23}$ Nótese que, además, el escriba españoliza el nombre.

$24<<$ hasta que casi se veía ya Medina, también muy pequeñita; y según se la veía a lo lejos parecía una sombra, y que sería muy fresquita $>$ (Ibídem).
} 
$<<_{i}$ Es que si, por un casual, vas a buscar un pollo o una gallina al gallinero por la noche, en vísperas de fiesta o porque la necesitas para un enfermo, no se quejan y alborotan los animalitos con dolor como cuando iban a buscar por la noche a los fusilados en la España entera con la veda levantada y ya siendo todos caínes determinados? $>>($ Duelo, p. 58);

El diminutivo en este caso indica lástima, conmiseración, y viene destacado, además, por implicar al receptor con la interrogación retórica que le propone. En el ejemplo siguiente, es juguetón: $<<$ la parecía el agua como un animalillo que se escapara otra vez a su/ madriguera $>$ (Sara, pp. 11-12).

Fray Juan en Segovia aquejado de la última enfermedad: $<<$ Y como si viera ${ }^{25}$ más con la fiebre, según las cosas que de/cía sobre que los árboles y los animalejos fueran de cristal reluciente o qué sé yo>> (Mudej. pp. 154-155). Reitera el aprecio de fray Juan por los animales que toman un aspecto insólito.

\section{-casilla/casita/casucha/casa/casa grande}

En La boda de Ángela, el narrador rememorando la infancia común, entre la emoción y el dolor de ausencia, le recuerda a su hermana Tesa: <<aquella casucha de guardar aperos [...] Teníamos llena la casucha de nuestras cosas $>>$ (p. 54).

Era un territorio propio, cómplice de sus secretos infantiles y de sus pertenencias; no se puede valorar más, como escribió A. Machado: se canta lo que se pierde.

Desde la madurez, el recuerdo le duele, no se puede dar marcha atrás al tiempo y a las vivencias $\mathrm{y}$, entonces

$<<$ luego todos estos años he pensado muchas veces en tirar la casilla, pero mamá se opuso, y allí están tu bicicleta y tu diávolo, y los patines de Lita, mis botas de fútbol, las raquetas; y como $\mathrm{si}^{26} \mathrm{se}$ acabaran de dejar allí, según los ves por la ventana al pasar cerca y te tienta asomarte > (p. 55).

¿Es despectivo aquí casilla? Ni mucho menos, sólo insiste en que cualquiera tiempo pasado fue mejor y si no, véase con cuánto dolor se separa de la hermana que va a profesar, pero a la que siempre tiene presente con dolor de ausencia ${ }^{27}$.

Las casas de los pobres siempre son casitas con ventanitas, las de los de Yepes, las de los vecinos de la aldea de Ojo Virule y Chichola Sacris, la de Sara era una casa, pero la de los criados, una casita (p. 10), quizá estemos hablando aquí de los objetos que pueden tener distinto tamaño, pero no de su valor puesto que valiosas son todas.

La Casa Grande es la del cacique y también las sedes de la Inquisición, son casas peligrosas, o la que habitan los poderosos, los ricos, poco sensibles ante las necesidades de los pobres, como la ya vista de Segovia.

\section{-Papel/ papelín/ papelillos/ papeles pequeñitos/ papelorios grandes}

\footnotetext{
${ }^{25}$ Subraya la anomalía.

${ }^{26}$ Destaca de nuevo el desajuste, la anomalía, entre una situación pretérita y las circunstancias actuales en que se revive. Cf. S. Fernández Ramírez, Gramática española.4. El verbo y la oración. Madrid, Arco/ Libros, 1986, p. 527.

27 "Porque el dolor de ausencia y el hambre son desgarros del alma y del estómago" El mudejarillo, p. 29.
} 
Andaba fray Juan escribiendo cuando se le cayó una letra, eso declara la mujer que

$<<$ le veía que sacaba un papelín del bolsillo, y luego la tinta y la pluma, y que se quedaba así un rato largo con la pluma en la mano, y después de mucho rato se ponía a escribir en el papel, apoyándolo en las rodillas $>>($ p. 80).

El primitivo, aunque esté identificado, es neutro en lo afectivo y el derivado, no.

Al salir del vientre de la ballena, se acogió en las descalzas de Toledo, triste y empavorecido por la experiencia $<<$ Pero luego, en seguida, lo que hizo / fue sacar unos papelillos viejos de dentro de su pecho, y ponerse a leerlos $>>$ (pp. 96-97), en los que contaba su estancia $<<$ en poder de este monstruo [...] que era un laberinto de muchas y maravillosas cosas y de versos de amor, y de una fuente, un jardín, una noche $>>$ (Ibídem). Los versos de fray Juan son fascinantes.

Al salir de la cárcel, también el escritor privado recibe unos escritos, en secreto, que poseía el inquisidor $<<$ unos papeles pequeñitos con apuntaciones $>>$ (p. 171), que se refieren a fray Juan, hermano de leche del juez. Naturalmente estos papeles, aunque importantes para el escritor, son inferiores, de ahí el adjetivo, a los del protagonista, cuyo contenido, como reconoce Micer Nicolás Doria, es $<<$ iBellissimo! ¡Proprio Petrarca! $>>$.

Ojo Virule siente un gran temor por los papeles oficiales porque los considera peligrosos:

$<<$ mientras el abogado sacaba los papeles y se ponía las gafas, ni siquiera caías en que también eran papelorios grandes de barba con firmas y sellos y que sonaban $\gg>$ (Duelo, $\mathrm{p}$. 136).

1.2. -ITO, -ITA. Es mucho más escaso en el uso que -illo, pero también, quizá por ello, muy marcado. Puede asumir valores muy positivos y negativos frente a -illo, como se ha visto.

1.2.1. Hay usos en que se prefiere -ito y en los que, como señala S. Fernández Ramírez, $<<$ se acumulan frecuentemente sentimientos de piedad, conmiseración, una modalidad de ternura y afecto $>>^{28}$.

-Aunque los animales pequeños se nombren con -illo. Los gatos son siempre gatitos; porque gatillo se menciona otra realidad. Escenas en las que se muestra el cariño y el mimo por unos gatos encontramos en Sara de Ur. Ese fue el regalo que, de Sedom, le trajo Abram. En ese Capítulo VII, mucho más extenso que cualquiera de los otros, se narra la llegada de Lot y lo sucedido en Sedom. Abram recuerda su estancia allí y se hacen lenguas de la belleza de la ciudad; sin embargo, el escriba no emplea ningún diminutivo, si no es para el regalo, y es que Sara nunca estuvo allí, por tanto, el narrador, que hace protagonista a Sara -como indica el título-, no muestra afecto, relata y describe con objetividad.

$<<$ Éste, para tu esposa. Pero ten cuidado, amigo. Ahora es un gatito, pero ya es como una mujer: hermoso e incomprensible, mimoso y zalamero, y también celoso y vengativo. [...] Y,

\footnotetext{
${ }^{28}$ En Strenae, 1962.
} 
cuando Abram vio hacer ¡fu! al gatito, pensó en seguida: Es como Sara, cuando está esquiva.. Y se rió.

El beduino dio, luego, de beber un poco de leche de cabra al gato ${ }^{29}$, pidio un cestillo con un paño de lino y lo acostó. [...] y, luego, Abram, cuando volvía de Sedom a casa, iba muy despacio en su asna con el cestillo entre las manos. Y el gatito fue una sorpresa para Sara, que nunca había visto una bestezuela tan hermosa [...]

-Es como la luna de hermoso-dijo >> (p. 63).

Y Abram se preguntó $<<$ ¿Acaso no era esta bestezuela más hermosa que cualquier rey envuelto en púrpura? >>. Está entusiasmado.

A la sorpresa se añade la admiración de Sara por el animal nunca visto al que valora mediante una hipérbole.

-En La boda de Ángela, cuando Tesa va a ingresar en el convento, se encuentra la familia con una escena propia de Francisco de Asís o Juan de la Cruz, la hermana portera:

$<<$ Llevaba en su mandil azul ${ }^{30}$ tres gatitos y los estaba dando un biberón mientras hablaba de las judías, los tomates, las patatas; (p. 98).

y el narrador reconoce que, de no haber sido por este encuentro, el cuarto de hora de espera $<<$ un siglo hubiera sido $>>$. ¿Cabe una valoración más positiva cuando se trata de entretener una espera interminable para separarse de la hermana más querida?

En una de las visitas del narrador a su hermana, ésta le cuenta que a la hermana priora le han regalado <<un gato que es todo negro como el Morito nuestro >> (p. 68): cosas importantes.

Es, desde luego, una familia singular: $<<$ Papá vendió el Rolls, y prefería un forito descapotable $>>$ (p. 62). Los invitados, al aparecer Teresa Soldati, $<<$ no pudieron disimular su sorpresa ante su sombrerito eduardiano y su estola de seda $>$ (p. 106); es toda una provocación por parte de la madre $\mathrm{y}$, con sorna, lo relata el hijo porque se ha logrado el objetivo: que les parezca ridículo y dejarlos en ridículo. En los dos casos, denota afecto, pero de distinto signo.

-El <<escritor privado $>>$ se refiere a Juan, antes de ser frailecillo, llamándolo mocito, mientras intenta distintos oficios hasta que, por fin, encuentra acomodo en el hospital. DRAE ya recoge la acepción $<<$ mozo de pocos años $>>$. Sin embargo, a pesar de ese valor léxico del diminutivo, creo que está valorando la formación o el aprendizaje del adolescente en capítulos fundamentales para su futuro: El empleo, El hospital, Socius turturis y La huida.

1.2.2. Se emplea en construcciones ponderativas.

A la muerte del cacique, decían las mujeres

$<<$ que se ha muerto el Julito, el gallo y el gallito $>>$ (p. 50).

\footnotetext{
${ }^{29}$ Se está distanciando de él.

${ }^{30} \mathrm{El}$ color azul es siempre muy apreciado por el autor. $<<_{i}$ Y puede haber algo tenebroso que sea azul? $>>$ (Seg. Abec. (p. 270).
} 
La aposición refleja ponderativamente la prepotencia del difunto. Al ir los elementos apuestos coordinados se acumulan sus valores. Hay que señalar que son dos estructuras isosilábicas -heptasílabos- que riman formando un pareado que contribuye también a poner de relieve la intención: la cantilenación de que hablaba el autor.

Chichola Sacris, en el velorio, decía:

<<¿Así que eras el gallo y el gallito, el amo del corral, eh, Julio Lorenzana?>> (p. 147).

Hay aquí una ironía al dirigirse al difunto, mediante una interrogación retórica señala lo que en él era más peculiar y lo ha perdido, y un sentimiento de liberación en quien así se expresa $^{31}$.

También Ojo Virule sentencia:

$<<$ este otro velorio del Julito, gallo padre del corral entero, gallo gallito que ya dejaste de amolar por siempre jamás amén $>(\text { p. } 52)^{32}$.

Se reitera una vez más el ejercicio del derecho de pernada y otros abusos continuos $<<$ este don Julio Lorenzana buen cacicón era, un señor de horca y cuchillo $>>$ (p. 49), reconoce el cabo Pérez-; y de ahí el verbo amolar tan significativo y el final sentencioso e insistente, $<<$ por siempre jamás amén $>>$, subraya lo despreciable. Los dos términos son una aposición ponderativa a la anterior explicativa, se repite la misma idea y ahora los términos van yuxtapuestos.

Estamos en la postguerra, pero el miedo no ha cesado, y la guerra sigue siendo una referencia constante. Así, don Ramón Nonato, el <<extrañado por ideas políticas $>>$ (p. 62), que llegó al pueblo y se integró tanto que vino a ser el Tío Telas, les comenta $<<$ lo mismo mismito era allí entre los rojos $>>$ (p. 108), intensificando y ponderando con la repetición de términos que encarece, aún más, el valor de lo+adjetivo. Lo ya dicho: todos fuimos caínes.

1.2.3. En contraste con el primitivo:

copa /vs/ copita

$<<$ vuelve a coger los papeles que sonaban como si $^{33}$ ardiera el cuartelillo y estuviera chisporroteando y dice: ¿una copita de anís, Ojo Virule? ¿A cuenta de qué venía, ahora, la copa?, pero me la trajo un número [...] y me la tomé de golpe. Aunque hubiera sido dinamita, lo mismo me la habría tomado, pero era buen anís tal como el de esta otra copita que aquí me ha puesto usted, ahora, señora María, y que me ha recordado aquella otra o la que Chichola Sacris estuvo buscando y no encontró para darnos fuerzas cuando el velorio de don Acisclo, el

\footnotetext{
${ }^{31}$ Cuando se descubrió que Chichola Sacris despistaba a las gallinas para que entraran en su casa y hacer con ellas un caldo para el hijo tísico, Julio Lorenzana lo castigó a un paseo por el pueblo esposado y colgandóle una gallina entre las manos, "el paseillo de vergüenza pública" (p. 134), el resto de los habitantes seguía estando mudo: primero, porque lo compacedían, segundo, porque se quedaron estupefactos ante la incomprensión, o la crueldad, del cacique.

${ }^{32}$ Declarando dice Ojo Virule $<<$ un cacicón como nadie, y faldero y prendido a cosa de mujeres mayormente $>>(p$. 92).

${ }^{33}$ Cf. nota 21.
} 
cura viejo, que parecía que se reía, aunque sería el relente de la mañana y las ensoñaciones de la hora, era seguro, y con una copita pasaría > (p. 121).

Con el diminutivo nombra las disfrutadas en la intimidad o las tomadas con deseo de darse ánimos. Copa es la que le ofrece el cabo quien, con un deseo de captatio benevolentiae, la llama copita.

\section{papeletas /vs/ papeletitas}

$<<$ Lo contrario que las papeletas salvadoras de Chichola Sacris, un cacho pequeñito de papel como de fumar casi: Pedro Pedroso Pérez confesó y comulgó a tantos de tantos de mil novecientos tantos: alas de mi salvación fueron >> (p. 121)

$<<$ Y, desde entonces, luego ya, fui todos los años a cumplir con la Iglesia para que me dieran mi papeletita por si acaso, porque nunca se sabe lo que puede suceder y tienes que tener los papeles. $>>$ (p. 39).

A pesar del empleo del primitivo, será por el adjetivo y la repercusión que tuvieron, me parece más afectiva papeleta, quizá después, como se trata de prevenir, no se ve el peligro inmediato, sólo hace referencia al tamaño o es la ironía de cumplir y mentir.

Sigue diciendo Ojo Virule:

$<<$ Ya no suena el señor Lerreus ${ }^{34}$ pero en tiempos de la República y antes era un talento, y, ahora, dicen que se ha muerto y se ha confesado y todo, como cada quisque ¡a ver qué vida, a hincar el pico como todos y a por su papeletita! >> (p. 55).

El miedo a la muerte, común a todos los mortales, les lleva a proveerse del salvoconducto que siempre se rechazó. Muestra aquí el hablante de nuevo su ironía y el sentimiento antiguo de la muerte igualadora.

\subsubsection{Asociado a nombre propio:}

Los vecinos de la aldea del Duelo tienen cada uno su mote, pero los caciques son $<<$ el don Julito $>>0<<$ el Julito $>>$ y su padre $<<$ don Pablito $>>$. Según A. ALONSO, $<<$ el sufijo -ito es despectivo y rebajador aplicado al enemigo $>>$. Mantiene al mencionarlos la cortesía obligada con el título de respeto incluido, pero aprecio no se les tiene. $<<$ La doña Elvirita $>>$ y $<<$ la doña Anita $>>$ les son más indiferentes. $<<$ La Paulita $<<$, la hija de la cachicana, tampoco les merece respeto.

Afecto sí muestra en $<<$ Rosita $>>$ que es, además, una muchacha joven. Y el dolor de la madre ante la muerte de su niño: $<<$ mi Luisito se ha ido al cielo $>>$ (p. 146), donde el posesivo es fundamental.

1.2.5. Asociados con este sufijo se presentan adjetivos y adverbios, aunque en mucha menor cantidad que los sustantivos. En ningún caso podrían haberse combinado con otro sufijo, luego la oposición se basa aquí en la presencia/ausencia del diminutivo.

Subraya la debilidad y muestra la conmiseración en $<<$ con el niño chico entre los brazos, el que luego se murió consumidito y más loca la volvió $>>$ (p. 146).

\footnotetext{
${ }^{34}$ Se refiere al Presidente del Partido Radical, don Alejandro Lerroux, también llamado, por entonces, don Ale.
} 
La posición de inferioridad del número Anselmo González con respecto a sus superiores, pero sacando pecho ante sus inferiores se indica con ese ponerse a la máquina $<<$ bien sentadito y estirado como se ponía $<<-$-p. 91-. El contraste entre la sumisión, servilismo, si hiciera falta, y el orgullo. Distinto es el encarecimiento de la compostura de los niños que hacían la cola en Fontiveros $<<$ muy serios y quietecitos $>>$ (p. 14).

Don Ramón Nonato era tan buena persona que nadie comprendía por qué se le había extrañado $<<$;Cómo era, además, tan poquita cosa! $>>$ (p. 46), era también un manitas y la mar de ingenioso. Por tanto, el diminutivo está destacando su inocencia.

Muchas tretas idea el cabo Pérez a ver si consigue que Ojo Virule declare lo que pasó en el duelo,

$<<\mathrm{Y}$ va luego y manda al número Eugenio Palma a hacer algún menester a la puerta del cuartelillo, y, así, tan ricamente nos quedamos los dos solitos, como cuando íbamos al huerto a probar los tomates $>>$ (p. 112);

pero aquél también es ingenioso y sabe lo que le debe a su amigo Chichola Sacris. Ambos buscan restablecer la confianza para ganarse la mutua complicidad, tras la amenaza del cabo, Ojo Virule responde: $<<$ Mejor aquí lo aclaramos, usted y yo solitos $>>$ (p .116). Hay un encarecimiento de la amistad al margen de la obligación.

Con emoción y entusiasmo, dice el narrador de La boda $<<$ en cuanto se quitara aquel disfraz de novia, sería igualita que tú $>>$ (p. 107). Se insiste en la semejanza. Y de Francisco, se encarece su trabajo bien hecho: <<apilaba la leña bien igualita $>>$ (Mudej. p. 78). Y su novia Ana, antes lavandera en el río, valora sobre todo la habitación donde está el telarcillo porque $<<$ estaba junto a la cocina y era bien callentita $>>$ (p. 52).

En $<<$ la mismita sala $>>$ Duelo (p. 117) refuerza la identidad.

Con adverbios tiene un sentido intensificador, subraya el modo $<<$ [la puerta] la cerraba despacito $>>$ (p. 144), para que no se escapara la gallina y poder cogerla. Con estas gallinas despistadas se hacía el caldo para alimentar al hijo tísico, el Anastasio Conejo. ¿Había o no que cerrar con tiento la puerta?

La complicidad que se establece entre Toñín y la Rosa es el descubrimiento del placer, pero, sobre todo, el gozar del calor humano y el compartir un secreto: <<cuando entró la Rosa en tu habitación y preguntó bajito: ¿estás dormido?>> (p. 129).

Subraya la premura. La pobre Roja Ranera era la encargada de borrar los rastros de los fusilamientos de la noche anterior: $<<$ cuando iba yo a su casa por la mañana prontito $>>$ (p. 95 ), porque $<<$ había que enterrarlos de mañanita pronto $>>$ (p. 60). En ambos casos se está encareciendo el hacerlo en secreto, antes del despertar de los vecinos.

Subraya la proximidad: en la ciudad, donde lleva el carbón a casa de Toño, Ojo Virule charla con la señora María y con la Rosa y hace otras tareas, $<<$ de propio para una carta cerquita $>>$ (p. 78).

\subsubsection{Empleos de -ito con valor negativo.}

-A Ojo Virule, aunque, o tal vez, porque es alguacil, le amedrentan los papeles oficiales, está asustado por tener que declarar ante el cabo Pérez: $<<$ Y tienes que contar a por a y be por be, todo bien clarito $>>$ (p. 44) y esta $<<$ declaración enterita $>>$ (p. 91) se recogerá en 
$<<$ Papeles todos grandes y de barba eran, que son los papeles temerosos de la justicia, con las letras como garrapatas o alacranes, o peor todavía, escrito a máquina clarita $>>$ (p. 121). Los adjetivos subrayan el riesgo del declarante y la intención de quien instruye el proceso.

-En casa de Teresa Soldati hay un retrato de la Principesa, $<<$ una amiguita de nuestro trasabuelo $>>$ (p. 18), expresa toda su carga picante e irónica. Como se dirá más adelante: fue una actriz ennoblecida después por el Papa.

Empleo de doble diminutivo -ito en un sintagma:

$<<$ [La Rosa] Es una muchachita delgadita y muy blanca, muy rubia, con pelusilla de melocotón en las mejillas >> (Duelo, p. 17).

Se alaba aquí la juventud y la debilidad, porque Toñín también era endeble por entonces y ambos se conchababan para combatir el frío y la soledad y compartir $<<$ el calorcillo $>>$.

\section{3.-Otros sufijos diminutivos}

1.3.1. -UELO. Era la alternativa a -illo en la literatura medieval y hasta el siglo XVIII. No hay que olvidar que también, como -illo, era de ascendencia latina (<-ǑLU) y se aplicaba a lexemas latinos que acababan en -i. A pesar de su decadencia hoy, sigue manteniendo su valor, no necesariamente sólo diminutivo o despectivo, como dice Beinhauer ${ }^{35}$.

Los sustantivos derivados en -uelo pueden tener un sentido dimensional, asociado a entes de un tamaño reducido, pero no por eso valorados negativamente: de $<<$ una aldehuela cercana $>$ (p. 19), procede la viuda que ocupará la casa de los Yepes en Fontiveros.

Al abandonar la casa, éstos, porque saben lo que es la necesidad, le dejan un ajuar modesto, pero suficiente: $<<$ En la alcoba, la ventanita tenía también su pañizuelo blanco $>>$ (pp. 19, 106 y 125); lo modesto no está reñido con la hermosura y el decoro; eso es lo que se está destacando.

Semejante es la situación en:

$<<$ llevando su puchero junto al pecho y la otra mano sobre el pañizuelo que tapa al pucherillo, como los curas llevan el viático $>$ (p. 14),

donde se insiste, además, en la veneración por el objeto.

Aún puede el gesto subrayar un sentimiento: <<se secó una lágrima con un pañizuelo>> (p. 107).

A fray Juan, ya desde niño le privaban la llama y el fuego, las luces y las sombras, y por eso queda extasiado ante los espejuelos de los candiles (p. 38); al correr el tiempo él será una Llama de amor viva o su alma saldrá $<<$ con ansias en amores inflamada $>>$. Los espejuelos no son trampa, son el reflejo de la llama, la respuesta a la llama o ¿la misma llama?.

${ }^{35}$ Cf. El español coloquial. Madrid, Gredos, 1973, p. 243. 
El $<<$ escritor privado $>>$ reside en una posada en la que le roban su cartapacio los inquisidores, aunque su mechinal es de difícil acceso y hay que pasar por la habitación donde se guardan $<<$ las luces de la casa para la noche $>>$ y allí había: $<<$ las pajuelas para encender y las despabiladeras $>>$ (p. 73), también él ama la luz, pero el objeto de que se sirve para producirla es humilde, y quiere proyectarla sobre fray Juan.

La muerte de éste fue tremenda, queriendo atajar la septicemia el cirujano cortaba, sajaba, estrujaba y el enfermo se acuerda de cuando era niño y $<<$ se había clavado una agujuela $>>$ (p. 160), una minucia comparada con la pasión de Nuestro Señor que él recordaba entonces. Se valora, no obstante, el compartir el dolor.

El diminutivo -uelo se asocia, también, a seres animados. El regalo de Abram a Sara, traído de Sedom, fue muy valorado por todos: el donante, el que lo porta y el receptor: $<<$ Tomó una de esas bestezuelas en sus manos y le dijo a Abram $>>$ y Sara $<<$ nunca había visto una bestezuela $\tan$ hermosa $>$ (p. 63). Hay que tener en cuenta que Sara ignora el nombre de esta especie desconocida por ella.

Y el mismo vocablo se emplea de nuevo en El mudejarillo $<<_{i Y}$ cómo es, entonces, que un hermanillo nuestro, como un frailecillo de nada entre las bestezuellas, hizo esta traición? >> (p. 75).

Todos los diminutivos del contexto son valorativos con un afecto positivo, pero el último se está refiriendo al ratoncillo que, inconscientemente traidor, descubrió los papeles a los inquisidores. Como el borriquillo mencionado, no es culpable.

Teresa, la fundadora, es para sus coetáneos $<<$ la monjuela $>>$ (p. 78), con tantos problemas como Juan y tan denostada. El diminutivo aquí, tal vez, sea irónico por el carácter de la monja y por la transcendencia de su reforma.

El $<<$ escritor privado $>>$ juega con una homonimia: judigüelos son una variedad de judías verdes y como tal planta hortense se cita en el Paisaje, pero también los cultivaba fray Juan en el conventillo de Granada; admirados los hermanos, le preguntaban si no estaba ajardinando el huerto al modo del de la Alhambra, y él contestaba: <<-Sólo son unos judigüellos $>>$ (p. 131); con amor por las verduras y con humildad, como siempre. Pero también se aplica, por homonimia, a los descencientes de judíos, gente de poca importancia, como los mudejarillos, a los que, siempre que tuvieran posibles o la situación lo aconsejara, el genealogista podría cambiar sus orígenes: $<<_{0}$ traiga ascendencia rústica a pobres judigüelos aterrorizados $>>$ (p. 119), el adjetivo es un valorativo que insiste en la indefensión y el diminutivo, en la ponderación.

El día en que el mocito conoció al Maestro León, éste está $<<$ mirando el agua, de donde venía el agua y cómo corría luego por un arroyuelo entre la hierba $>>$ (p. 64).

Este arroyuelo es un regato harto significativo. En $<<$ una granja $>>$, por los últimos días de junio, Marcelo, Sabino y Juliano

$<<$ se sentaron juntos, a la sombra de unas parras y junto a la corriente de una pequeña fuente, en ciertos assientos. Nasce la fuente de la cuesta que tiene la casa a las espaldas, y entrava en la huerta por aquella parte, y corriendo y estropeçando, parecía reyrse. 
(-De los nombres de Cristo, p. 149) ${ }^{36}$.

Y comenzaron un diálogo modélico que, fray Luis todavía estaba pensándolo, pero que el escritor privado conoce. Tanto el agustino como el carmelita apreciaban mucho el agua. Éste en Granada,

$<<$ añadió, mientras miraba allí en la huerta a un regatillo:

-Mas yo sé bien de otra fuente que mana y corre. $>>$ (p. 132).

Se le da un carácter animado al añadir la preposición. Lo mismo que se humanizó $<<e l$ puchero $>>$ ya comentado.

Sólo se asocia con un adjetivo. Entre las muchachas a las que corteja Is'hac, Qasiáh <<era sonriente y gordezuela $>>$ (p. 98), se asemeja a la madre por el primer rasgo, se distingue de ella por el segundo que se valora con el diminutivo: cada uno se considera independientemente.

En el recibimiento al enviado del Obispo de Ávila, en Fontiveros, estaba todo el pueblo y había $<<$ rostros gordezuelos y enjutos $>>$ (p. 10). Por contra, el Monseñor que va a casar a Ángela tenía el $<<$ rostro redondito y lleno $>>$ (p. 133), era importante y hasta miembro de la Rota.

Cambia de signo cuando se aplica a la Principesa quien tenía, en el retrato, $<<$ las manos un poco gordezuelas ${ }^{37}$ y con un rosario entre ellas $>>$ (p. 12); nos recuerda a don Guido.

1.3.2. El sufijo-ETE se aplica a dos términos. Mozalbete, con doble marca, por la época en que el joven dio un estironcillo, físico y psíquico, y decidió hacerse fraile, es muy valorado porque parece que así evitaba el riesgo de ser un enano -vid. supra-; ello, no obstante, a Teresa, cuando lo conoce $<<$ la parecía casi un mozalbete, y tan delgadillo, tan poquita cosa $>>$ (p. 70) y tenía ya veinticinco años: otra vez el contraste entre la talla física y la espiritual.

En femenino lo emplea el autor, con frecuencia, en sus diarios y ensayos, aplicado al término cultureta con el que se refiere a la cultura oficial al uso: siempre con valor negativo.

-ete /vs/ -ón. Contrasta la edad y la talla.

Un mocete, por su edad, era el pobre Anastasio Conejo, cuando lo detuvieron. Pero tenía un aspecto de <<un mocetón como un castillo $>>$ (p. 35), <<un mocetón nos parecía a todos cuando a la cárcel fue $>>$ (p. 119), de donde volvió hecho una ruina físicamente.: $<<_{i} Y$ por qué tuvo que ir a la cárcel siendo sólo un mocete y casi un niño? $>>$ (Duelo, p.59), y al día siguiente: $<<$ ya ni rastro quedaba del mocete, como una gallina que te roba la zorra por la noche $>>$ (p. 119).

De su estancia en el Penal de Palencia volvió tísico y $<<$ se os murió el mocete $>>$ (p. 36). El diminutivo subraya la compasión que merece la tragedia del muchacho y de sus padres -nótese el uso del dativo ético-; indica la desmesura entre la presunta responsabilidad del muchacho y la repercusión de la condena.

1.3.3. -EJO sólo se añade a sustantivos. También es un sufijo diminutivo heredado del latín (<-ICǓLU), y en la Edad Media aún se usa simplemente con carácter diminutivo.

\footnotetext{
${ }^{36}$ Madrid, Cátedra, 1997.

${ }^{37}$ ¿Delata sus orígenes o quiere esconder su historia?
} 
Montado en un machejo -pp. 154, 156 y 158- hace fray Juan su último viaje, el de Segovia a Úbeda, ya muy enfermo. Se está ponderando la mansedumbre del mulo y su poca traza.

El señor Calixto, en el mesón, <<sacó un librejo >> del zurrón (p. 95), que era su único equipaje, y al leerlo suspiraba. De ello se deduce que era un libro muy apreciado por su dueño.

El zagalejo se titula uno de los cuentos de El grano de maíz rojo. Ya, desde el título, se muestra la ternura por el muchacho y la conmiseración por su final.

\section{-Cocineja/vs/ cocina}

$<<$ La cocineja ésta de Chichola Sacris te daba confianza $>>$ (p. 135).

Unas líneas antes, en su evocación, ha llamado a la misma estancia cocina y ha señalado la astucia del abogado para llevarle a un lugar que le era familiar y sonsacarle más fácilmente. Está hablando de conejos y de ratas, de su aversión -mezcla de miedo y admiración por la habilidad del letrado-, parece como si hubiera un cruce de ideas entre la cocina, los conejos, el corral y la comadreja, de donde cocineja, por la viveza para tenderle la trampa y el perjuicio consiguiente. Como la partideja, esta habitación también le ha traicionado porque le ha hecho bajar la guardia.

1.3.4. Los formados con -UCO son escasos y se aplican sólo a dos sustantivos. Un ventanuco precisa fray Juan en su celda para que entre luz y escribir -p.71- y mirar al exterior -p.153-. Dada la austeridad del frailecillo, -uco señala el aprecio por las actividades imprescindibles que el ventano permite realizar.

Mujeruca es un término muy empleado por el autor cuando quiere subrayar la bondad y la naturalidad sin doblez de una mujer ya mayor, humilde y desvalida. Así recoge en sus diarios una experiencia que vivió en Olmedo:

$<<$ La palabra almalafa llama la atención de la dueña de la tienda que cree que es una palabra
de gente baja y sin educación, y le dice a la pobre mujer: querrás decir un mantón. Y ella
contesta: Sí, sí, pero se siente humillada, y, entonces, creo que debo intervenir en la
conversación y digo por mi parte. Está muy bien dicho almalafa. La mujeruca me lo
agradece con una sonrisa, y añade mi pobre madre siempre la llamaba así $>>.{ }^{38}$

Toda la escena rebosa el cariño por la mujer y por la lengua que habla.

También será una mujeruca la que cuente ante el Tribunal cómo a fray Juan se le cayó una letra y, al dársela ella, el fraile se lo agradeció diciéndole que era la más importante -pp. 79, 80 y 106-. Como en el caso anterior, se agradece la ayuda prestada con una confidencia.

En La boda de Ángela aparecen dos. Desde la explanada de la ermita se ve por el camino:

$<<$ una mujeruca vestida de luto y llevando un asno por el ronzal $>>$ (p. 41) en contraste con las galas y alhajas de los forasteros.

\footnotetext{
${ }^{38}$ José Jiménez Lozano. Unas cuantas confidencias, Madrid, Ministerio de Cultura, 1993, p.11; y más por extenso en Los tres cuadernos rojos, p. 108.
} 
Cuando la familia acompaña a Tesa al convento, desde el tren ven a otra mujer que se despide desolada de una muchacha $<<$ Cuando subió, la mujeruca trastabillaba y echó a correr un poco con los brazos extendidos, desgarrados $>>$ (p. 97), el mismo desgarro que siente el narrador al separarse de la novicia. En todos los casos, marcan la compasión.

1.3.5. El sufijo-UCHO, -UCHA también se emplea poco. El señor Juan González, el candilero, tenía una tienducha en los soportales -Mudej. p.37-que encandilaba a los niños que venían a verle trabajar. Seguramente la tienda sería pequeña, pero no el aprecio de los muchachos por lo que allí se fabricaba y se vendía y, sobre todo, el de Juan que está deslumbrado.

Se aplica también a un adjetivo. Un arriero procedente de Andalucía le trae a la señora Catalina nuevas de su hijo $<<$ Que es pequeño de su cuerpo y delgaducho $>>$ (p. 104), el partitivo delimita y el adjetivo insiste en sus pocas carnes: lo que caracteriza al medio fraile.

$<<$ Ángela se ha recogido su vestido de novia para dar un paso de baile con una mocita alta y desgarbada, delgaducha y con unos ojos grandísimos $>>$ (p. 93);

Ambos indican ternura.

1.3.6. El diminutivo -ICO sólo aparece en una ocasión, en El mudejarillo, referido al protagonista. En el mesón, dos corchetes andan comentando cómo aquella noche, durante la ronda, se les escapó un enamorado y según ellos era $<<$ el galán de monjas un mocico $>>$ (p. 95). Creo que la interpretación de los guardias tiene un matiz pícaro y, tal vez, indique la socarronería del transcriptor del diálogo al ver lo errados que están.

1.3.7. El sufijo-ÍN, propio del noroeste peninsular, es también poco frecuente en el autor. Se aplica a un nombre propio Toñín -Duelo, p.65-, un hipocorístico del habla familiar que nombra al chiquillo enfermo de difteria, quien, a sí mismo, se llama Toño en su afán de ser mayor.

El muchacho alemán que vive en casa del Julito le es particularmente antipático a Ojo Virule, no sólo porque sea un metomentodo, sino incluso por su físico:

$<<_{j} Y$ se necesitan chereles, digo yo, ahora y donde sea, traer quien los haya traído aquí a España a estos chicos alemanes tan grandotes y desarrollados a comer a dos carrillos en las Casas/ Grandes y que crecían a ojos vistas como si les regasen, habiendo tanta miseria de chiquirrinines españoles que había aquí, que no abultaban estos renacuajos lo que un escuerzo a cuenta del hambre y las calamidades todas de la guerra y de las siete colas que arrastra luego la guerra consigo! >> (pp. 68-69).

Todo ello en una oración exclamativa y con un diminutivo con doble sufijación extraordinariamente afectivo que destaca la doble antítesis entre: $<<$ chicos alemanes tan grandotes $>>$ y $<<$ chiquirrinines españoles $>>$. Insiste en la compasión que le produce al hablante ver a estos muchachos hambrientos y enclenques de la aldea.

Asociado a un adjetivo lo emplea con cariño y compasión la mujer que ocupó la casa de Fontiveros: $<<-j$ Qué será ahora de ellos: de la señora Catalina y el mozo, y el otro, pequeñín, tan delgadillo! $>$ (p. 20).

1.4. Hay, finalmente, una serie de diminutivos, en tono exclamativo, que muestran la piedad, la lástima, para con los otros. 
$<<$ Pobrecillo! $>>$ es el más habitual. Las estraperlistas que trapichean con garbanzos o lentejas, ante el cabo, <<se ponían a temblar, ipobrecillas! >> (p. 111, Duelo); o los corderos que se habían matado en la mesa de la cocina $<<y$ ni la tocábamos de horror que nos daba, ipobrecillos!>> (La boda, p. 57); o los enfermos del hospital que pedían un espejo

$<<$ aunque el mocito nunca se lo daba, por caridad: para que no viesen su figura y su cara, ¡pobrecillos! Y entonces, se acordaba de la tórtola sola mirándose en el agua. ¡Pobrecilla también! ¿No? > (Mudej. p. 53).

O la harina y el aceite que escondía Engracia en $<<$ la sepultura de mis hijos, ellos lo comprenderán, ¡los angelitos! $>>$ (p. 117).

2. NO SON ESCASOS LOS AUMENTATIVOS, aunque sean menos frecuentes que los diminutivos.

2.1. El grupo más numeroso está integrado por los en -ÓN. De ellos un grupo amplio son adjetivos deverbales, a veces sustantivados, que indican la reprobación de una conducta.

En el Duelo se emplean: <<pero lo que oían los escuchones $>>$ (p. 23), <<porque como de escuchón y mirón estaba en todas partes $>>$ (p. 103), $<<$ dijeron también esas rezonas $>>$ -p.93-, <<0 fueran muy rezomes $>>$ (p. 99), $<<$ con lo gritona que soy $>>$ (p. 98). Pero lamentable es el feto, el aborto de Anita Flores <<como carne sin cuajar del todo y temblona y blanca $>>$ (p. 138). Con un interés por halagar al pequeño, el tú presente, se dice: <<ya eres un grandullón $>>$ (p. 130).

En $L a$ Boda $<<$ allí se iba sentando aquella gente, siempre con frío y arrecida hasta los huesos, quejicosa y llorona $>>$ (p. 56). Censura expresa también este aumentativo, con doble sufijo, de un adjetivo que ya de por sí connota negativamente: $<<y$ frescachona que fue en su juventud $>>$ (p. 97). Y a la tía se la pinta así <<cínica, pesetera, sensual, comillona, apoltronada, dormilona, beata $>>$ (p. 21). La secuencia es toda negativa. Para ganarse al niño: $<<-Y$ ahora ¿a que no salta el grandullón? [...] Porque siempre me llamaba el grandullón aunque no tendría más de diez años $>>$ (p. 92) Es, como en el caso citado del Duelo, un aumentativo activo que busca la colaboración del receptor. Apunta al deseo de los niños de hombrear.

$\mathrm{Su}$ antónimo sería pequeñajo, que puede expresar tanto el aprecio como el desprecio. Al encontrarse en Mancera el señor Ahmed y fray Juan, éste <<seguía siendo pequeñajo y alegre $>>$ (p. 82) no deja de ser una impresión positiva por parte de quien tanto le había encarecido que $<<$ no creciera nunca, nunca $>>$ (p. 55), es decir, que no perdiera su candor.

Sin embargo, Ihsma'el se considera un hombre frente a Is'hac y por eso lo zahiere diciéndole: $<<$ iTonto e ignorante, que sólo eres un pequeñajo y no sabes nada de la vida! $>>$ ( $p$. 74) y, ante Sara y Abram se justifica de la misma manera: $<<$ Pues que no me busque, ni vaya conmigo. Sólo es un pequeñajo que no sabe nada de la vida > (Ibídem). Marca el desprecio hacia la niñez por quien está en la pubertad.

En El mudejarillo son escasos:

$<<$ también voceones y absolutos cuando mandan $>>$ (p. 25). 
Lo ridículo o grotesco se indica con $<<$ los ojos redondos y saltones $>>$ de El maniquí. Otro grupo menos amplio está integrado por sustantivos derivados de sustantivos.

$<<Y$ allí estaban los paquetes sobre la mesona, como la llamábamos, ¿te acuerdas?: la que estaba y está adosada a la ventana y está hecha de dos grandes tablones de nogal, sobre la que nos decían que se habían matado corderos, y ni la tocábamos de horror que nos daba. ¡pobrecillos! >> (Boda, p. 57).

A la visión dimensional se agrega lo horrible de su función.

$<<$ Pero yo sólo he ido allí unos días, de niño; y no me acuerdo apenas de cómo era la casa, excepto de aquel portalón enorme en el que se podía entrar con el coche de caballos o con el automóvil $\gg$ (p. 69).

$<<$ Aquel $>>$ insiste en la distancia temporal, $<<$ enorme $>>$, en el tamaño. Puede ser que, desde la mirada de un niño, la entrada resulte más impresionante de lo que es en realidad; en cualquier caso, insiste en el distanciamiento: no olvidemos que se trata de un palacete de la familia.

Los hay relativos al aspecto físico. El pobre crucificado que acabó de muñeco de feria, El maniquí, tras haber sido espantapájaros, era una imagen grotesca por la falta de habilidad del tallista, pero no deja de ser lamentable su destino debido a la pérdida de la memoria de los vecinos:

$<<$ El rostro parecía el de un tragaldabas de feria con la boca abierta y las mejillas mofletudas, los ojos redondos y saltones, y un bigote burdo y negro que teminaba por sus extremos en dos caracolillos ridículos [...] y por la herida que mostraba al lado derecho pintada de verde y con los bordes rosáceos cabría perfectamente el puño de un hombrón $>>\left(\right.$ Grano, p. 23) ${ }^{39}$

Se está hablando de tamaño, pero un hombrón puede ser ridículo o inspirar temor, como el hombre del saco de los cuentos infantiles ${ }^{40}$.

El tamaño y su carácter endiablado, lioso y malintencionado, se está aseverando en $<<$ la Petra Canaria siempre había sido una mujerona $>>$ (Duelo, p. 26).

Relativos al tamaño y la edad es: <<un mozancón como un castillo, y subía y bajaba a fray Juan del machejo $\gg$ (p. 156), el doble sufijo indica aquí no sólo su tamaño, sino su habilidad, era medio inocente -como Francisco, el hermano de fray Juan-, pero entrañable y cariñoso.

Repulsa denota la voz cacicón que reprueba una conducta y se emplea varias veces en el Duelo

$<<$ que el Julito Lorenzana buen cacicón era $>$ (p. 49), <<era un cacicón como nadie >> (p. 92).

\footnotetext{
${ }^{39}$ Nótese que abundan en la descripción los sufijos de todo tipo.

${ }^{40}$ Recuérdese también la canción tradicional: “Antón, Antón, no pierdas el son/ porque en la alameda/ dicen que hay un hombrón con un carretón/ que a los niños lleva”.
} 
Consecuencias nefastas va a tener la única vez en que Chichola Sacris $<<$ sacó el vozarrón y le ordenó: ¡Levántate, Conejo, y arrodíllate $>>$ (p. 107), el esfuerzo llevará a la muerte al pobre Anastasio.

\subsection{El sufijo-OTE no aporta siempre connotaciones negativas:}

$<<$ un hijo de aquel muchachote de nuestra edad que era quien amasaba y atendía el horno y era un poco inocente: se llamaba Ángel $>>$ (Boda, p. 129)

se contrasta el tamaño con la simpleza, pero ¿se puede valorar más que llamándolo Ángel?.

Sin embargo, repulsa indican los usos siguientes:

$<<$ traer quien los haya traído a España a estos chicos alemanes tan grandotes y desarrollados a comer a dos carrillos $>>$ (Duelo, p. 68),

$<<$ un maestro amigo tuyo y de tus amigotes $>>$ (p. 112)

$<<$ ¿No decíais tú y tus amigotes $>>$ (p. 120).

Se está mencionando a los otros, los disidentes, los diferentes. Pero para Ojo Virule son sus amigos.

Rechazo absoluto hay en:

$<<y$ fue risa de amigotes y correveidiles de su marido $>>$ (Boda, p. 32).

2.3. Con el sufijo $-\mathbf{A Z O}$ se nombra un golpe seco que se da con lo que indica el lexema:

$<<y$ cuando el Julito fue a coger un asa de la caja le dio el don Pablito un manotazo tal que así>> p. 138),

$<<y$ tenía que acudir a lo de darlas [a las gallinas] un palo en la cabeza [...] / un porrazo bien dado y en el acto: la práctica $>$ (pp. 144-145).

Al tamaño y la fiereza se refiere en $<<$ un perrazo que te ataca $>>$ (p. 132). 42).

A lo rústico valorado positivamente: $<<$ con su sotana corta y sus botazas $>>$ (Boda, p.

3. EN CONCLUSIÓN, en las obras estudiadas domina el tono conversacional -Duelo en la Casa Grande y La boda de Ángela- y la transcripción de la intimidad en Sara de Ur y El mudejarillo. Son textos fundados en el diálogo en los que el narratario no es el lector -en aquéllos- $\mathrm{y}$, en éstos, se nos comunica el interés por los personajes del narrador interpuesto. Ello favorece el empleo de apreciativos. Si su uso está en franco retroceso y, en verdad, no son habituales en los narradores coetáneos, aquí es un uso vivo, variado y muy significativo.

Las confesiones del autor nos explican cuál es su concepción de la lengua, la que ya defendieron Juan de Valdés, Fray Luis de León y la que recomendó don Quijote: $<<$ llaneza, muchacho, no te ensalces que toda afectación es mala $>$; y cuál es su actitud ante los personajes, escucharlos y dejarlos hablar, ser una especie de amanuense; por eso $<<\mathrm{el}$ 
escritor lucha con las palabras y tiembla ante ellas, busca y vuelve a buscar humildemente aquellas que nombran lo que es preciso nombrar, exactamente aquellas y no otras $>>{ }^{41}$.

Si el autor se declara jansenista es, entre otras razones, porque comparte su ideal estético: $<<$ lo simple natural $>>^{42}$. Como puede deducirse de los ejemplos antes citados.

Del estudio del uso y valor de los aumentativos y diminutivos que, rara vez, son dimensionales, se desprende que tienen, sobre todo, un valor apreciativo y de ahí se infiere la actitud del autor hacia sus personajes. Hay mucha ternura, respeto e interés por escucharlos y por verlos vivir. Se les deja explicarse con sus palabras, mostrando sus afectos, así por ejemplo cuando el $<<$ escritor privado $>>$ se encuentra $<<$ con un mi amigo $>>$ (el señor Miguel, p.167), insistiendo en el sentimiento.

Hablan como saben, en una lengua carnal que matiza cada significado, de ahí los múltiples valores que puede mostrar un apreciativo, él solo o en oposición a otros: ternura, repulsa, aprecio, respeto, miedo...

El hecho de que domine, con mucho, -illo y el mantenimiento del valor afectivo de uelo -semejante al de -illo-, nos indican una fidelidad al habla de estos personajes de cualquier época que valore lo humano, o en otras situaciones: el habla rural siempre fue más rica y respetuosa con la tradición hasta que la televisión ejerció su influencia uniformadora.

-Illo sólo toma valores negativos en boca de los enemigos nunca en la del narrador, sus antónimos, si los hay, son los otros sufijos ${ }^{43}$.

Se emplean tanto en proposiciones principales como en cláusulas subordinadas.

En los textos de protagonista destacado, si éste no está presente, no hay apreciativos: así en Sara de Ur, ni en la descripción de Sedom ni en el viaje a Moryac; ni en El mudejarillo en La recomendación. Tal vez porque el transmisor ignore cuál hubiera sido la actitud de los interesados si hubieran vivido la experiencia. Incluso, pueden quedarse sin palabras y ello es extraordinariamente significativo, es lo que le ocurre a fray Juan mientras está en el vientre de $<<$ La ballena $>>$ o cuando no hay $<<$ Ni rastro de nada $>>$. Sara desconoce el nombre genérico del regalo y se respeta su ignorancia. El transcriptor respeta, también, sus silencios. El narrador no quiere confesar cuál fue el regalo de Tesa tan decisivo, silencio: sólo iba destinado a Ángela. Otra prueba de honradez narrativa. En todos estos casos, indica respeto por la autonomía de los personajes, el narrador dice lo que oye y sólo lo que quieren decir.

Algunos sustantivos especificados con $<<$ grande $>>$, como hemos visto, son terroríficos. Cuando se trata de indicar sólo un concepto dimensional se emplean adjetivos.

Se ensalza lo humilde y se teme al poder y a quien lo ejerce, porque, confiesa el autor, $<<$ las pequeñas vidas de los seres humanos más pequeños son las que pueden decirnos algo nuevo. Los grandes de este mundo ya nos han dicho y repetido todo ad nauseam. Han tenido

\footnotetext{
${ }^{41}$ Una estancia holandesa, pp. 21-22.

${ }^{42}$ Ibídem, p. 29.

43 Aunque también puede tomarlo en el habla conversacional del autor; en Una estancia holandesa se lee: $<<$ perfectamente imbécil eso de la tercera edad. En el fondo es como un sarcasmo o una burla de humor negro, pero es también sacarina, simulación para no llamar a la realidad por su nombre, y la formulita ha tenido un éxito clamoroso $>>$. (p. 138).
} 
siempre la historia entera a su disposición, pero los pequeños seres humanos no: ellos nunca fueron escuchados, ni entrevistos siquiera, hablan en un susurro y todos sus océanos y mundos de alegría o su sufrimiento están sin descubrir $>>^{44}$.

El valor de los apreciativos se destaca, en ocasiones, mediante otros recursos: el posesivo, el polisíndeton, la onomatopeya, la comparación y la ponderación. De la misma manera que se emplean otros recursos para destacar el vocablo primitivo, cuando al hablante le conviene.

La lengua se ha puesto al día, y la reconocemos como nuestra, sin menoscabar su belleza y peculiaridad. Y todo el sistema lingüístico está en función de la veracidad, $<<$ cuando escribo me esfuerzo en no mentir $>>$, dijo Seifert, $<<$ sobre todo cuando se fabula $>>$-apostilló José Jiménez Lozano- porque, según él, la literatura $<<$ nunca miente $>>$. Así creo que es y así nos lo muestra.

\footnotetext{
${ }^{44}$ Una estancia holandesa, p. 44.
} 
. 